Prevision model and empirical test of the box office results for sequels

\author{
Bertrand Belvaux ${ }^{\text {a }}$ \\ Rémi Mencarelli ${ }^{\mathrm{b}}$ * $^{*}$ \\ ${ }^{a}$ IAE Dijon - CREGO E.A. 7317 - University of Burgundy \\ 2 boulevard Gabriel, BP 26611, 21066 Dijon Cedex, France \\ Tel : +33 380396470 \\ E-Mail : bertrand.belvaux@u-bourgogne.fr \\ ${ }^{\mathrm{b}}$ IAE Savoie Mont Blanc - IREGE - University of Savoie Mont-Blanc \\ 4, chemin de Bellevue, 74944 Annecy-Le-Vieux Cedex, France \\ Tel: +33450092400 \\ Email: remi.mencarelli@univ-smb.fr
}

* Corresponding author 


\title{
Prevision model and empirical test of box office results for sequels
}

\begin{abstract}
As studios release an increasing number of movie sequels, scholars have begun to examine this strategic choice. Prior studies use standard models of box office performance to evaluate sequels' performance and have mainly compared the box office results of the original movie with those of its sequel. However, sequels hold a unique position in the motion picture market since they are strongly associated with the original movie. Using the accessibilitydiagnosticity framework, this research investigates the drivers behind the success of sequels and examines specifically the original movie's impact through the role of reviews. The results - from 232 movies (116 original movies and 116 first sequels) - demonstrate the direct impact of the original movie's reviews on the sequel's performance.
\end{abstract}

\section{Keywords}

Movie industry; Review; Sequel; Box office; Accessibility-diagnosticity framework

This research did not receive any specific grant from funding agencies in the public, commercial, or not-for-profit sectors. 


\section{Prevision model and empirical test of box office results for sequels}

\section{Introduction}

The lifespan of movies in theaters has been steadily decreasing over the last several years. This is due to the abundant and constantly increasing number of films released, a sharp growth in distribution (through the number of screens per movie) and alternative means to access films (video-on-demand, streaming, screening rooms), which has led to studios perceiving the release of new movies as highly risky. Instead, over the past few years, they have capitalized on past successes, exploiting well-established movies with enduring reputations and strong consumer preferences (Eliashberg et al., 2006), and thus focusing more on motion picture sequels than on stand-alone movies (Filson \& Havlicek, 2018). With this strategic orientation, studios have aimed at minimizing risk by capitalizing "on the success of an original movie by producing another film that reprises the same characters evolving in a new situation" (Sood \& Drèze, 2006). In 2019, the top ten box office successes worldwide were sequels, compared to only two in 2000.

Given the enormous economic impact of sequels in the movie industry, scholars have begun to examine this strategic choice (Filson \& Havlicek, 2018). Some studies have used sequels as a control variable in existing models of box office performance; others have evaluated and compared the box office results of sequels with those of the original movies or contemporaneous non-sequel movies (Ravid, 1999; Basuroy \& Chatterjee, 2008; HennigThurau et al., 2009; Moon et al., 2010; Dhar et al., 2012). Most existing studies use standard models of box office performance to evaluate sequels' performance, even though sequels hold a unique position in the motion picture market since they are strongly associated with an original work (Chisholm et al., 2015). Some studies equate sequels with brand extension, thereby indirectly associating the sequel with the original movie (Moon et al., 2010), but they 
have neglected to examine the role of any pre-existing signals from the original movie, especially the role of reviews. However, experiential information generated about the original movie (i.e., reviews from consumers and critics) can be used by moviegoers to make inferences and judge the sequel and, in turn, affect the box office performance of the sequel. Hence, this research investigates what drives the success of sequels and demonstrates that over and above the usual characteristics that affect the performance of a movie (i.e., characteristics of the film, studios' actions and third-party information), the drivers of a sequel may also include the reviews associated with the original movie. Using the accessibility-diagnosticity framework, which has been recently applied to motion picture box office performance (Joshi \& Mao, 2012; Knapp et al., 2014; Carrillat et al., 2018), we hypothesize and empirically show that these peripheral signals do not originate from the sequel itself, but impact the sequel's box office performance, specifically during the release phase. This result explains the unique position sequels hold in the movie market compared to stand-alone movies and why a specific performance model should be developed for sequels. In addition to the indirect effect of the original movie on the sequel through a brand extension effect, we highlight the direct impact of the original movie's reviews on the sequel's performance with the accessibility-diagnosticity framework, demonstrating that reviews from an original movie can be applied to a sequel and thus have an effect over time. From a managerial perspective, our results suggest that it would be interesting for cinema executives to reactivate positive reviews of the original movie at the launch of a sequel.

In this paper, we first review the literature dedicated to the box office performance of motion pictures and, based on the accessibility-diagnosticity framework, we develop a specific model for sequels. The methodology used and the results obtained are then presented. To test the model, we use data from 232 recent movies (116 original movies and 116 first sequels). 
Finally, the contributions and limitations of the study are noted, and avenues for future research are proposed.

\section{Conceptual framework}

\subsection{Motion picture box office performance: original movie versus sequel}

Researchers have produced a substantial number of studies analyzing the box office performance of films. Like any other product, a movie's success is based on the interaction between supply and demand. The supply strategy is developed by two key players in the motion picture industry, the producer and the distributor; the major studios usually assume these two functions internally (Hadida, 2009). The producer defines the main characteristics of a movie: genre, country of origin, MPAA ratings, selection of the director and the actors. The associated budget is also defined by the producer according to the expected performance of the film and its anticipated profits (Dhar et al., 2012). The producer entrusts the distributor with a mandate to define the marketing actions associated with the release strategy (PrietoRodriguez et al., 2015). In order to maximize revenues, the distributor determines the optimal combination of resources - such as advertising expenditures and distribution intensity through number of screens - by estimating the movie's potential audience.

With regard to demand, a movie's attractiveness is based on its reputation and image among consumers (Liu, 2006). Even if a movie is an original experience (Nelson, 1970; Chen et al., 2012), potential moviegoers can develop preferences without consuming the film. They use signals that resonate with their past experience. For example, the genre, the actors or the director are signals that can influence a priori the consumer's preference for a movie. The audience can also use external information such as expert reviews or interpersonal communications (Holbrook, 2005). The influence of third-party information used by moviegoers has been demonstrated in various studies (Liu, 2006; Karniouchina, 2011; Lee et 
al., 2015). Third parties are people who share their experiences and opinions of a film with potential moviegoers. These information sources are usually perceived as credible and trustworthy (Liu, 2006; Chakravarty et al., 2010), and moviegoers view them as an indicator of quality (Hennig-Thurau et al., 2006). Third-party information is all the more important for entertainment products because it sparks discussions among consumers (Liu, 2006).

Consequently, a vast majority of moviegoers base their decision processes on third-party information (Karniouchina, 2011). Many studies have analyzed the role of third parties and distinguished:

- the sources: expert-based reviews (professional critics' reviews) and non-expert reviews (consumer reviews). These third parties play the role of influencer or predictor (Basuroy et al. 2003);

- the characteristics: volume (total number of reviews, which contributes to the reputation and awareness of a film's existence; i.e., the informative dimension) and valence (nature - positive or negative - of the reviews, which contributes to the movie's image; i.e., the persuasive dimension) are the main characteristics ${ }^{1}$ used to describe reviews (Liu, 2006).

To sum up, the box office success of a movie is based on three main factors: the characteristics of the film, the intensity of the marketing strategy (mainly through the advertising budget and number of screens) and the reviews (from critics and moviegoers).

In this research context, a number of studies have analyzed sequels' performance (Table 1). Broadly speaking, the term "sequel" is used to refer to the production of a film based on the

\footnotetext{
${ }^{1}$ Other characteristics were identified, including consistency (Karniouchina, 2011), dispersion (Godes \& Mayzlin, 2004), entropy (Dellarocas et al., 2007) and observability (Dellarocas et al., 2010).
} 
success of a first, original movie (Sood \& Drèze, 2006). These studies of sequels aimed to analyze their box office performance from two perspectives.

[insert Table 1 here]

First, some studies compare sequels with non-sequel movies. Initial studies use the sequels as a control variable. Some conclude that this variable does not affect the existing models (Basuroy et al., 2003; Liu, 2006), while others show that it has a significant impact (Basuroy et al., 2006; Hennig-Thurau et al., 2006; Boatwright et al., 2007; Karniouchina, 2011). Other studies have evaluated the box office performance of sequels by comparing them to nonsequel movies released during the same period. Basuroy and Chatterjee (2008) show that sequels do better than contemporaneous non-sequels; Dhar et al. (2012) confirm this result. In both studies, the authors provide explanations based on brand extension theory (Aaker \& Keller, 1990). They conceptualize sequels as brand extensions, as do several other studies (Sood \& Drèze, 2006; Hennig-Thurau et al., 2009). In other words, the studios use existing brand names and look for ways to build on the similarity of characteristics between the original movie and the sequel (e.g., genre, stars, directors, storyline) in order to enhance brand awareness. The perceived similarity between the original movie (i.e., the brand-parent category) and the sequel (i.e., the extension category) leads to a process of assimilation (Sood \& Drèze, 2006), shapes quality perceptions (Hennig-Thurau et al., 2009) and positively influences the box office success of the extension (Basuroy \& Chatterjee, 2008; Dhar et al., 2012).

Second, some studies compare the sequel's performance with that of the original movie. Using an economic approach (Lazear, 2004), Basuroy and Chatterjee (2008) assume that the box office earnings of the original film will always be greater than those of the sequel due to the inevitable phenomenon of regression to the mean. They show this effect empirically on a sample of 11 sequels. Using a larger sample and a model based on brand extension value, 
Hennig-Thurau et al. (2009) provide empirical evidence that sequels generate high average revenue and reduce the associated risk. Using an individual-level analysis, Moon et al. (2010) emphasize that sequels have a better box office performance due to the original movie's brand power, the initial success of the original film and the established fan base of the original. They confirm this assumption during the release phase but find that this effect dissipates quickly after the first two weeks. Moon et al. (2010) also observe that sequels receive lower ratings from moviegoers as a result of satiation (lack of novelty and surprise for an experiential product). Dhar et al. (2012) use a sample of movies spanning 26 years and demonstrate empirically that sequels attract more moviegoers than stand-alone movies released during the same period, but fewer than the original movies. However, they generate more profit than do the original movies. Filson and Havlicek (2018) extend this to global film franchises and show that the performance of sequels tends to decline as extensions are introduced. Several factors can explain the contradictory results obtained in these studies: the instability of the results given the small numbers of sequels in some of the samples, the different study periods in changing and complex environments and the adoption of different time horizons to determine a motion picture's box office performance. Although they arrive at different results and conclusions, these studies generally compare the sequel's box office results with those of its original movie or a contemporaneous non-sequel movie. They do not examine the specific mechanisms underlying a sequel's box office performance, in particular the role of preexisting signals from the original movie. These mechanisms deserve attention and should be considered in light of the initial release of the original movie on the market (Chisholm et al., 2015).

\subsection{Specific mechanisms of sequels' box office performance}


Based on previous research dedicated to box office performance, we assume that, like standalone movies, sequels' box office performance depends mainly on the characteristics of the movie (genre, director, actors, MPAA rating, country of origin, producer status), the intensity of the studios' actions (production budget and screens) and the reviews (from critics and moviegoers) of the sequel. We do not propose formal hypotheses about these effects as they are largely supported by previous empirical studies.

In addition to these expected effects, we assume that the original movie affects the sequel's box office performance through the persistence of its reviews. To identify these specific mechanisms, we use the accessibility-diagnosticity framework (Feldman and Lynch, 1988), which has been successfully applied in the context of motion picture box office performance (Joshi \& Mao, 2012; Knapp et al., 2014; Carrillat et al., 2018). According to this framework, consumers rely on the most diagnostic and accessible cues to make a judgment. More precisely, a piece of information is more likely to be used as a cue in a judgment if it is perceived as relevant to the judgment (diagnosticity), it is accessible for use in the judgment and other information is less accessible (accessibility). We use arguments based on this theoretical framework to explain the influence of the original movie's reviews on the sequel's box office performance.

First, consumers will use available signals to assess the quality of the sequel during the release phase (Akdeniz \& Talay, 2013). In this context, moviegoers can draw on existing and credible signals based on their own consumption experience of the original movie and/or on information generated by other moviegoers who saw the original movie. Consumers will also associate the sequel with the original movie (Basuroy et al., 2006; Hennig-Thurau et al., 2009). In other words, information generated about the original movie (through consumption and/or by third parties) contributes a priori to the reputation and image of the sequel. These cues are also more instructive than factual information (e.g., genre, MPAA ratings) as they are 
experiential information. Consequently, because of their accessibility and diagnosticity, the reviews associated with the original movies become an important information source for sequel judgments, especially during the release phase. Consequently, moviegoers can be motivated to choose to see the sequel early, without waiting for the emergence of sequelspecific reviews.

However, according to Joshi and Mao (2012), in the first week after release, direct experiential cues about the sequel become more accessible. Consequently, the effect of the information used to evaluate the movie quality earlier on, including the reviews of the original movie, is likely to dissipate. It is thus possible to assume the reviews of the original movie influence the short-term box office performance of the sequel but not its long-term performance.

Previous studies suggest both a volume and a valence effect of reviews on box office performance (Table 1). However, for expert-based reviews, the volume effect is less persistent over time, in contrast to the volume effect of consumer reviews (Larceneux, 2007). The volume of critics' reviews also remains broadly constant, with each expert evaluating all the films that are launched. Finally, several studies highlight the prominence of a valence effect for critics’ reviews (Desai \& Basuroy, 2005; Basuroy et al., 2006; Dellarocas et al., 2007). Therefore, we assume that the volume and valence of consumer reviews and the valence of critics' reviews of the original movie can directly impact the short-term box office performance of the sequel.

H1a. Consumer reviews (volume and valence) of the original movie have a positive impact on the sequel's short-term box office performance (first week) but do not affect the sequel's long-term performance (after the first week). 
H1b. Critics' reviews (valence) of the original movie have a positive impact on the sequel's short-term box office performance (first week) but do not affect the sequel's long-term performance (after the first week).

Second, the effect of the original movie's reviews on the sequel's box office performance will probably be moderated by the time interval between the release of the two movies (Basuroy \& Chatterjee, 2008; Filson \& Havlicek, 2018). The persistence of reviews has already been documented in different studies (Godes \& Silva, 2012; King et al., 2014). As noted by King et al. (2014), persistence of reviews means that existing reviews significantly influence future ones. According to the accessibility-diagnosticity framework, a short time period makes the reviews of the original movie more accessible to potential consumers of the sequel. In consequence, a short time period between the two movies should increase the influence of the original movie's reputation and image on the sequel's short-term box office performance.

H2. The shorter the time interval between the release of the original movie and the sequel, the stronger is the impact of consumers' and critics' reviews on the sequel's short-term box office performance (first week).

Third, the reviews generated for the original movie can influence the box office performance of the sequel by affecting the reviews of the sequel. Like Duan et al. (2008), we consider reviews to be an endogenous variable. In other words, consumers' and critics' reviews of a sequel depend on the reviews previously generated for the original movie. First, for a sequel, the evaluation can be general due to the emergence of brand equity (Moon et al., 2010). The great similarity between the original movie and the sequel, which increases the perceived diagnosticity of cues associated with the original movie, will favorably impact the endogenous nature of the reviews (Joshi \& Mao, 2012). Second, considering the consistency 
and perceived similarity between the sequel and the original movie (Sood \& Drèze, 2006), the assessment criteria will probably be the same and will be reactivated in a similar way (Moon et al., 2010). Therefore, by distinguishing the consumers' and critics' reviews, we posit that the reviews associated with the original movie can influence the sequel's box office performance through their impact on the sequel's reviews. Formally:

H3a. The consumer reviews (volume and valence) of the original movie have an indirect and positive impact on the sequel's long-term box office performance through the consumer reviews of the sequel.

H3b. The critics' reviews (valence) of the original movie have an indirect and positive impact on the sequel's long-term box office performance through the critics' reviews of the sequel.

Figure 1 summarizes the model of box office performance for a sequel. The model is based on standard effects identified for a movie (intra-movie effects). It also explicitly integrates the influence of the original movie and the associated signals that predated the release of the sequel (inter-movies effect).

[insert Figure 1 here]

\section{Sequel box office prevision model}

\subsection{Data}

Original data were collected on 232 movies (116 original movies and 116 first sequel movies) on the American market between 1999 and 2014 (Appendix 1). The data were collected from boxofficemojo.com, the-numbers.com, rottentomatoes.com and imdb.com (like Chakravarty et al., 2010). As reviews on the IMDb platform began appearing in 1999, franchises that started before this date are excluded from the database. Indeed, certain factors are likely to 
change strongly over such long periods of time (e.g., economic conditions, critics' and audiences' tastes) and can therefore alter results (Elberse \& Eliashberg, 2003).

Numerous studies assess box office performance dynamics by considering both the overall performance and that of the first week following a movie's release (Basuroy et al., 2006). However, to test our hypotheses and avoid data nesting, we make a distinction between results in the first week (short-term performance) and after (long-term performance). To account for the temporal dimension, these data were adjusted for inflation over the period and for seasonal variations (annual and monthly trends). Seasonal correction coefficients were based on a broader film database (6,650 films shown over the same period).

We use three sets of variables to explain the commercial performance of a sequel: movie characteristics, studios' actions and reviews (Table 2).

\section{[insert Table 2]}

Like Hennig-Thurau et al. (2012), we choose several movie characteristics: country of origin (USA/outside the USA), status of the studio (major/independent), genre, MPAA classification, director and actors. For genre we use the four major categories on the IMDb website: action-adventure, animation, drama-thriller and comedy. Like Moon et al. (2010), two categories are used for the MPAA classification: R and non-R (PG-13, PG and G). To analyze the role of the director and actors (the two main actors), the total box office performance of their previous movies is used as an indicator of attractiveness (Hennig-Thurau et al., 2006). Using past success as a predictor of future success is the simplest indicator for measuring the effect of the director and/or "star" actors (Rein et al., 1987; Karniouchina, 2011). 
In addition, we include two main variables associated with studios' actions (Hennig-Thurau et al., 2006): the production budget ${ }^{2}$ and the number of screens at the movie's release. These reflect the ambition of the producer and distributor, respectively.

Finally, for the reviews, the valence of the critics' reviews was captured by the Metascore index from the IMDb website, summarizing and standardizing some thirty professional sources, the scope of the critic being constant (Hennig-Thurau et al., 2012). For consumers, the reviews variables were captured through the evaluations posted on the IMDb website (average score and number of ratings). For the temporal dynamic (Liu, 2006), the sequel's reviews were recorded during the first week (intra-movie effect) and those of the original movie from its release period until the date of release of the sequel (inter-movie effect).

\subsection{Model specification}

Like Zufryden (1996) and Elberse and Eliashberg (2003), we use log-log modeling. This makes it possible to take into account the multiplier effects of variables ${ }^{3}$ and analyze the effects in the form of elasticities. The logarithmic transformation of continuous data also reduces the strong variance between films and limits heteroscedasticity. Moreover, the formulation of a multiplier model is consistent with the multi-level theoretical models used to estimate the commercial performance of a movie (Duan et al., 2008). Finally, in order to compare results, we use the same choice process as in several other research studies looking at sequels (Elberse \& Eliashberg, 2003; Basuroy et al., 2006; Hennig-Thurau et al., 2006). The relationship between the endogenous variable and the exogenous variables is written as:

$$
\text { Revenue }_{i}=e^{\text {constant }} \cdot X_{i}^{a_{1}} \cdot e^{a_{2} \cdot Z_{i}} \cdot e^{E r r_{i}}
$$

\footnotetext{
${ }^{2}$ The production budget corresponds to what the North American film industry calls the "negative cost" or the expense of producing the film excluding distribution and promotional expenses. The amount is adjusted for inflation.

${ }^{3}$ For example, there will be no income unless a copy is presented.
} 
where $\mathrm{X}$ is the vector of continuous variables and $\mathrm{Z}$ the vector of dummy variables. ${ }^{4}$

In order to evaluate the original movie's impact on the sequel, the analysis was carried out in two stages: first, the test of the intra-movie model (internal effects of the sequel's performance) and then the test of the inter-movie model (effect of the original movie on the sequel).

\subsection{The intra-movie model of sequel performance}

The first step is to estimate the sequel's performance through its internal dynamics: the movie's characteristics, the studios' actions and the reviews. As mentioned in the conceptual framework, we made no hypotheses on these effects given their validation in previous studies. The production budget and the number of theaters can raise problems of endogeneity as they directly explain performance and are also determined by the expected performance of the film. A three-equation model is therefore used:

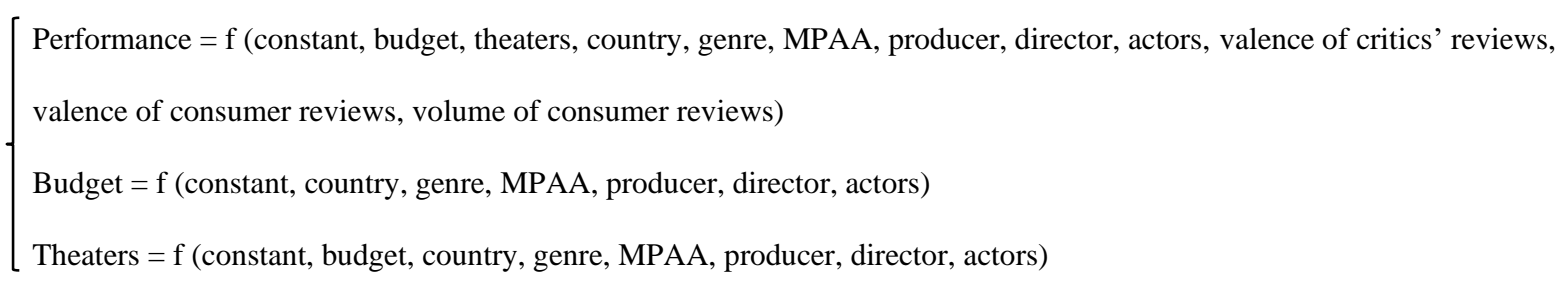

Parameters of the model were estimated using the structural equation modeling (partial least squares method). The classic model for forecasting a movie's box office performance is satisfactory in the sequel case (Table 3). The performance of a sequel thus depends at first mainly on studios' actions (production budget and number of theaters) and professional reviews, and then, after the first week, on spectator's reviews. The production budget positively affects the commercial performance of the movie $(\beta=0.251, \mathrm{p}<0.01$ during the

\footnotetext{
${ }^{4}$ Continuous variables are transformed into logarithmic format. Some values can take a zero value; the applied transformation is: $\mathrm{Y}=\ln (\mathrm{X}+1)$. Dummy variables are introduced in exponential form to reflect the absence of the factor.
} 
first week and $\beta=0.254, \mathrm{p}<0.01$ after the first week). The number of theaters also has a positive effect $(\beta=1.695, \mathrm{p}<0.01$ during the first week, $\beta=1.365, \mathrm{p}<0.01$ after the first week). The effects of reviews also play a role in the commercial performance of the sequel. The influence of professional reviews is strongest immediately after the film is released $(\beta=$ $0.584, \mathrm{p}<0.01$ ), before the influence of consumer reviews kicks in (both valence $\beta=0.441, \mathrm{p}$ $<0.01$, and volume $\beta=0.420, \mathrm{p}<0.05)$. On the other hand, the movie's characteristics do not affect the result. The "star" effect does not impact the sequel's commercial performance. These initial results remain broadly consistent with those identified in the literature regarding the commercial performance of a movie, with a key role played by studios' actions and reviews. However, we note that the movie's own characteristics have almost no effect on commercial performance, which suggests the predominant influence of the sequel as a brand (Sood \& Drèze, 2006).

\section{[insert Table 3]}

\subsection{The inter-movies model of sequel performance}

The second step is to analyze the box office release from an inter-movie perspective. This consists of assessing the extent to which a sequel's performance is affected by the original film. The analysis model is therefore based on explaining residuals of the first model. It reduces the number of parameters to be estimated and limits the endogeneity effects between the variables of the two movies (original movie and sequel).

We determine both the direct and the indirect effects of the original movie's reviews on the commercial performance of the sequel by using mediation tests on the hypotheses. Indirect effects are analyzed via the influence of variables related to the reviews of the sequel. This test follows the procedure described by Zhao et al. (2010) using the structural equation 
method. ${ }^{5}$ The objective is to use the sequel's reviews to analyze the direct and indirect effects of the original movie's reviews on the sequel's performance.

The results first highlight the direct effects of the audience reviews associated with the original movie on the sequel's performance (Table 4). The audience reviews of the original movie (valence and volume) thus directly affect the performance of the sequel in the first week $(\beta=0.458, \mathrm{p}<0.01 ; \beta=0.129, \mathrm{p}<0.01)$. However, after the first week, they no longer directly affect the performance of the sequel. Moreover, the professionals' reviews of the original movie do not directly affect the performance of the sequel in either the short (first week) or long term (after the first week). The results obtained therefore support H1a and reject $\mathrm{H} 1 \mathrm{~b}$.

In the sequel box office model, the time interval between the original movie and the sequel can moderate the effect of the original movie's reviews on the sequel's box office performance (H2). Regressions were performed with an interaction effect (number of months between the two movies) explaining the sequel's performance through the reviews of the original movie (Table 5). The time interval between the original movie and the sequel has a weak and negative effect on the relationship between consumer reviews (volume) and the sequel's short-term box office performance $(\beta=-0.005, \mathrm{p}<0.1)$. In other words, the shorter the time interval between original and sequel, the stronger is the effect of the consumer reviews (volume) on the sequel's performance. The effects of other signals associated with the original movie on the performance of the sequel are not moderated by the time interval; these include the valence of consumer reviews $(\beta=-0.009, \mathrm{n} . \mathrm{s})$ and the valence of critics' reviews $(\beta=0.001, \mathrm{n} . \mathrm{s})$. These results partially support H2. The nature of the reviews' characteristics can explain the results. The quantitative aspect (volume) of the reviews

\footnotetext{
${ }^{5}$ The analyses were performed by the Lavaan module of $R$ software for analysis of covariance structures and the partial least squares method with Smartpls software for verification.
} 
increases their accessibility, reactivates them easily and enhances consumer awareness of the sequel (Liu, 2006), contrary to the qualitative nature of the cues (valence of reviews from consumers and critics), which can have inconsistent effects over time (Godes \& Silva, 2012). Secondly, the results show the indirect effects of audience reviews of the original movie (volume and valence) on the long-term performance of the sequel (Table 4). A good audience evaluation of the original film thus generates a favorable opinion of the sequel $(\beta=0.484, \mathrm{p}<$ 0.01), which positively determines the sequel's box office results. Similarly, a large volume of reviews for the original movie positively affects the volume of reviews associated with the sequel $(\beta=0.837, \mathrm{p}<0.01)$, which then determines its commercial success. On the other hand, while the valence of critiques of the original movie affects the valence of the critiques of the sequel $(\beta=0.701, \mathrm{p}<0.01)$, there is no significant indirect effect on performance. These results therefore support $\mathrm{H} 3 \mathrm{a}$ and reject $\mathrm{H} 3 \mathrm{~b}$.

[insert Table 4 here]

[insert Table 5 here]

While these results only fully support two hypotheses (Table 6), they do confirm the unique situation of the sequel, which benefits from the previous existence of the original movie. Unlike an original movie, where audience reviews only can play a role after the first week given the time it takes for them to emerge (Liu, 2006), a sequel immediately benefits from the public reaction to the original movie, which will directly affect the short-term performance of the sequel. The results confirm the role played by some pre-existing experiential information - both informative (volume) and persuasive (valence) - associated with the original movie. Because of their accessibility and diagnosticity, reviews of the original movies accelerate the viewers' decision-making about the sequel during the first week. Moreover, the influence of the reviews of the original movie on those of the sequel emphasizes the endogenous nature of the reviews (Duan et al., 2008). Finally, consistent with the accessibility-diagnosticity 
framework (Joshi \& Mao, 2012), the direct impact of these quality signals becomes diluted as other quality signals directly associated with the sequel emerge.

[insert Table 6 here]

\section{Conclusion}

\subsection{Contributions to the literature}

In developing a model to forecast a sequel's box office performance, we make three main contributions to the literature. First, we identify the specific mechanisms underlying a sequel's box office performance and thus the need to develop dedicated performance models for sequels. Whereas the performance of a stand-alone movie is affected by cues related to a studio's prelaunch decisions (i.e., production budget, advertising budget, distribution intensity, star power, director) and cues related to third-party information (i.e., professional reviews from critics and consumer reviews) (Bharadwaj et al., 2017), the performance of a sequel is also affected by the experiential information associated with the original movie. These peripheral signals impact the sequel's box office performance during the opening week. This result explains why sequels hold a unique position in the movie industry and can have a competitive advantage compared to their contemporaneous non-sequel movies (Hadida, 2009). This strategy will specifically reduce the risk of failure, but does not necessarily ensure success (which is based more on the quality of the sequel).

Second, our paper adds to previous studies that have specifically analyzed sequels' performance. These studies have mainly compared the performance of the sequel with the performance of the original movie (Basuroy \& Chatterjee, 2008; Hennig-Thurau et al., 2009; Moon et al., 2010; Dhar et al., 2012; Filson \& Havlicek, 2018), using a brand extension effect to indirectly take into account the effect of the original movie on the sequel. Based on the accessibility-diagnosticity framework, the test in our model goes further by acknowledging 
the explicit impact of the original movie on the sequel's box office performance through the role of the reviews. The brand and product-related characteristics (genre, stars, director, storyline) are not the only signals affecting the performance of the sequel. The experiential information associated with the original movie and reactivated in this brand extension context will also directly impact the sequel's performance.

Third, our results demonstrate the persistence of reviews, whereas previous studies mainly emphasize the short-term effects of reviews in the context of a stand-alone movie's box office performance (Liu, 2006). Here, the accessibility-diagnosticity framework offers a convincing theoretical explanation for this persistence effect of reviews on sequels and confirms its relevance in assessing the effect of these signals (Carrillat et al., 2018). Specifically, the volume and valence of consumer reviews affect the sequel's short-term performance given the availability and credibility of the signals that guide moviegoers in their decision-making process by minimizing uncertainty. The direct impact of these experiential signals then becomes diluted as other direct experiential cues about the sequel become more accessible. Consequently, as expected, the original movie's reviews have no direct effect on the long-term performance of the sequel. Contrary to the idea that the influence of reviews diminishes quickly over time (Duan, Gu \& Whinston, 2008), this result suggests that reviews can be reactivated from an original movie to apply to a sequel and thus have an effect over time.

\subsection{Managerial implications}

From a managerial perspective, the results of this work can help studios during the development and launching of sequels, as the decision-making of the major studios regarding this type of movie remains a "complex equation" (Eliashberg et al., 2006).

At a strategic level, the existing reviews of the original movie are interesting signals available to the studios. First, analysis of these reviews can help studio executives select original 
movies for potential sequels that can be successfully launched onto the movie market.

Second, during the release phase, these signals can reassure risk-averse studio executives about a sequel's potential. While the existence of an original movie provides an overall revenue boost for the sequel (Moon et al., 2010), the reviews associated with the original movie will specifically facilitate the sequel's theatrical release. Third, the reviews of both critics and consumers will provide an indicator of the nature of the reviews that will be generated as part of a sequel.

At an operational level, our results encourage managers to call upon these quality signals during the release phase of the sequel. Currently, studios only have a short, one-off window to attract a potential audience: the average run for a movie is four weeks in a context where more films are launched each year (708 new movies were released throughout 2019, compared to 641 in $2018^{6}$ ) and where development and launch costs are increasing, especially for sequels (Bharadwaj et al., 2017). Therefore, the main objective for cinema executives is to use as many quality signals as possible during the release phase in order to reduce information asymmetry and ensure rapid commercial success for the sequel. Our results provide an incentive to studios to integrate reviews into their operating strategy more effectively, especially in promotional operations. They can reactivate these quality signals in two ways. First, studios can directly and explicitly refer to the reviews of the original film in the promotional campaigns at the launch of a sequel. They can be mentioned in trailers, teasers, posters or websites dedicated to the sequel by emphasizing the number of moviegoers who recommended the original movie (volume effect) or recalling good memories associated with the original movie (valence effect). Studios can also use internet ad campaigns targeting moviegoers who recommended the original film through display campaigns, for example. The importance of these reviews can also be mentioned in the press kits that the studios provide to

\footnotetext{
${ }^{6}$ Motion Picture Association Industry Report (2019)
} 
movie critics. The use of reviews in terms of their experiential nature can lead to a positive attitude towards the sequel in the opening weekend and reassure moviegoers who want to avoid purchasing a "lemon" (Akerlof, 1970; Carrillat et al., 2018). Secondly, studios can reactivate these signals indirectly by emphasizing the perceived similarity between the original film and the sequel. The aim here is to underline the existing proximity between the original film and the sequel, whether in the genre, the star cast, the director or the storyline. Studios can also facilitate this reactivation of reviews by reducing the time interval between the release of the two movies.

\subsection{Limits and perspectives}

This research has some limitations. It may be interesting to analyze in more depth the time horizon associated with commercial performance. Indeed, the model developed in this research distinguishes between short-term (revenue during the first week of movie screening) and long-term performance (revenue after the first week of movie screening). However, given the current speed of the emergence of reviews associated with new products (Hennig-Thurau et al., 2015), and using the accessibility-diagnosticity framework, analyzing the sequel's daily revenues would allow for a more detailed evaluation of how long the quality signals (access and relevance) associated with the original movie affect the sequel's success. It also seems relevant to adopt a differentiated time horizon with the reviews by distinguishing, like Berger and Schwartz (2011), the reviews generated in the launch phase (immediate word of mouth) from the ongoing reviews developed throughout the product's presence on the market (ongoing word of mouth). However, new products are likely to generate substantial reviews in the launch phase. Since sequels are by definition a derivative work, born out of a standardization rather than innovation approach, this distinction would make it possible to assess both the volume of reviews of a sequel throughout its presence in theatres, and the 
weight of the effect the reviews of the original movie have on those associated with the sequel. This perspective could also make it possible to examine the volume of reviews of critics whose weight is especially significant when starting a film (Larceneux, 2007).

Beyond a better consideration of the temporal dimension, other variables characterizing sequels should also be integrated into the proposed model. From this point of view, this research simplified the format by reducing the analysis to the impact of the original movie on the first sequel. However, studios are tending to develop longer and longer formats (Filson \& Havlicek, 2018), prompting consideration of the number of sequels to assess the persistence of these signals according to the place of the sequel in the franchise (Basuroy \& Chatterjee, 2008). Similarly, as in Sood and Drèze (2006), the homogeneous nature of movies could be integrated using indicators such as titles (descriptive or numbered, e.g., Terminator Genisys or Fast and Furious 8) or the continued participation of star actors from one movie to another. The degree of similarity between the movies (i.e., diagnosticity of the franchise equity) is likely to increase the reactivation effects of the signals associated with the original movie (Joshi \& Mao, 2012). It might also be interesting to distinguish the nature of sequels by incorporating an order perspective. Indeed, in this research, the term sequel generically covers all works derived from an original work with no distinction of the nature of the derivative works. However, studios deploy different script devices (i.e., prequel, sidequel, spin-off, reboot, remake, crossover). Integrating these script formats into box office forecasting models could also help refine the results.

Finally, the hypotheses proposed in this paper could be extended to other markets and product categories. First, this research drew from data from the U.S. market to test the box office forecasting model of a sequel. It might be interesting to assess the validity of the model in other markets, as the taste for this type of film product may vary depending on the cultural context (Akdeniz \& Talay, 2013). Secondly, this research was limited to the analysis of the 
theatrical movie market. However, there are other experiential products where companies minimize the risks of a new launch by capitalizing on the success of an original product. From this point of view, strategies in the publishing, video game or music industries could be similar to those implemented in the movie industry. It would therefore be interesting to examine the role played by quality signals associated with products of the same brand in these sectors. Similarly, it might be interesting to assess the role of these signals in the creation of a product providing a similar experience (film, video game, comic book, book) on multiple media platforms. 
Appendix - Movie sample

\begin{tabular}{|c|c|c|}
\hline 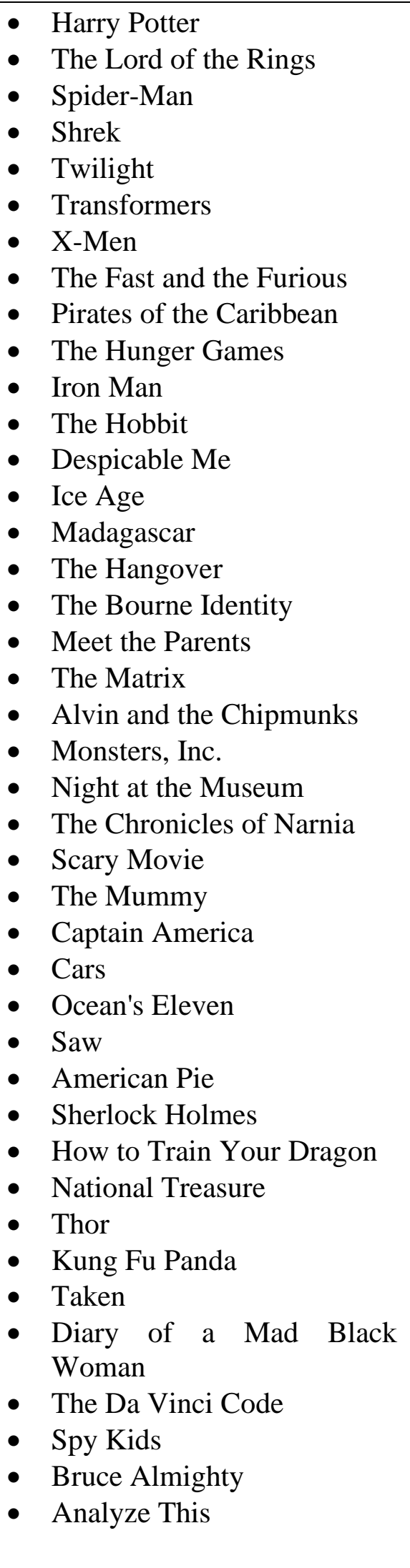 & 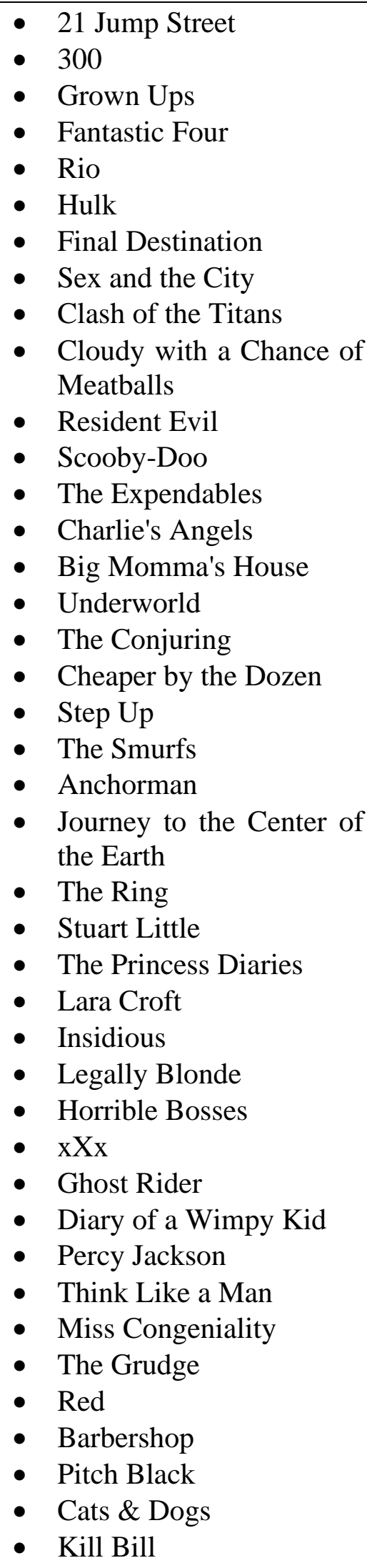 & 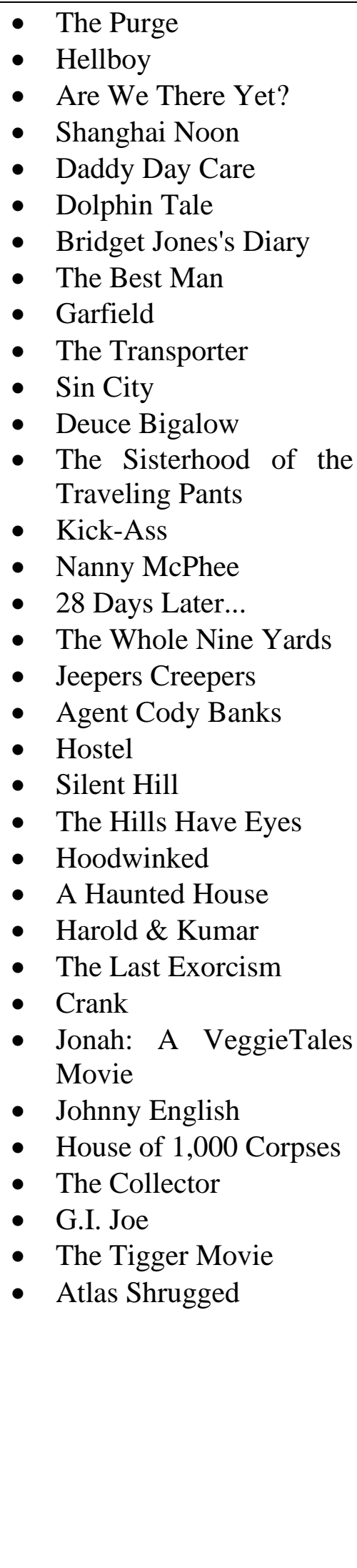 \\
\hline
\end{tabular}


Table 1 - Sequel's box office performance: literature synthesis

\begin{tabular}{|c|c|c|c|c|c|}
\hline \multirow[b]{2}{*}{ Authors } & \multicolumn{2}{|c|}{ Exogenous variables } & \multicolumn{3}{|l|}{ Endogenous } \\
\hline & Demand & Supply & $\begin{array}{l}\text { variable: } \\
\text { revenues }\end{array}$ & Movie sample & Performance of sequels \\
\hline Ravid (1999) & $\begin{array}{l}\text { Critics' reviews (volume } \\
\text { and valence) }\end{array}$ & $\begin{array}{l}\text { Production budget, MPAA ratings, } \\
\text { Presence of stars, Presence of } \\
\text { participants who were nominated for or } \\
\text { received awards, Film's release date }\end{array}$ & $\begin{array}{l}\text { Domestic, } \\
\text { international and } \\
\text { video revenues }\end{array}$ & $\begin{array}{l}175 \text { movies }(1991 \\
-1993)\end{array}$ & $\begin{array}{l}\text { Sequels are considered as a signal. } 11 \text { films are sequels in } \\
\text { the database. The sequel variable positively affects the box } \\
\text { office performance. }\end{array}$ \\
\hline $\begin{array}{l}\text { Basuroy et al. } \\
(2003)\end{array}$ & $\begin{array}{l}\text { Critics' reviews (volume } \\
\text { and valence) }\end{array}$ & $\begin{array}{l}\text { Production budget, Presence of stars } \\
\text { (actors and directors), Screens, MPAA } \\
\text { ratings, Film's release date }\end{array}$ & Weekly revenues & $\begin{array}{l}175 \text { movies }(1991 \\
-1993)\end{array}$ & $\begin{array}{l}\text { Sequels are considered as a control variable. } 11 \text { films are } \\
\text { sequels in the database. Models are not affected by the } \\
\text { presence of sequels. }\end{array}$ \\
\hline $\begin{array}{l}\text { Basuroy et al. } \\
(2006)\end{array}$ & $\begin{array}{l}\text { Critics' reviews (valence } \\
\text { and homogeneity), } \\
\text { Consumer reviews }\end{array}$ & $\begin{array}{l}\text { Advertising expenditures, Screens, } \\
\text { Major distributors, Competition, } \\
\text { Expected performance, Presence of } \\
\text { stars, Sequel }\end{array}$ & $\begin{array}{l}\text { Revenues (opening } \\
\text { week, second week } \\
\text { and beyond) }\end{array}$ & $\begin{array}{l}175 \text { movies }(1991 \\
-1993)\end{array}$ & $\begin{array}{l}\text { Sequels are considered as a signal. } 11 \text { films are sequels in } \\
\text { the database. Sequel and ad expenditure have a positive } \\
\text { interaction impact on the box office revenues. }\end{array}$ \\
\hline $\begin{array}{l}\text { Hennig- } \\
\text { Thurau et al. } \\
\text { (2006) }\end{array}$ & $\begin{array}{l}\text { Critics' reviews, Consumer } \\
\text { reviews }\end{array}$ & $\begin{array}{l}\text { Budget, Presence of stars, Cultural } \\
\text { familiarity (sequel, remake, adaptation), } \\
\text { Advertising expenditures, Screens, } \\
\text { Production budget }\end{array}$ & $\begin{array}{l}\text { Revenues (opening } \\
\text { week, beyond the } \\
\text { opening week) }\end{array}$ & $\begin{array}{l}331 \text { movies }(1999 \\
-2001)\end{array}$ & $\begin{array}{l}\text { Sequels are considered as a studios' action. Number of } \\
\text { sequels in the database is not specified. Sequels positively } \\
\text { affect the box office revenues during the opening week. }\end{array}$ \\
\hline Liu (2006) & $\begin{array}{l}\text { Critics' reviews (volume } \\
\text { and valence), Consumer } \\
\text { reviews (volume and } \\
\text { valence, pre- and post- } \\
\text { release) }\end{array}$ & $\begin{array}{l}\text { Production budget, MPAA ratings, } \\
\text { Genres, Presence of stars, Screens (first } \\
\text { week), Movie's life (in weeks) }\end{array}$ & Weekly revenues & 40 movies (2002) & $\begin{array}{l}\text { Sequels are integrated in preliminary analysis. They have } \\
\text { no significant effect on the aggregate box office revenues. }\end{array}$ \\
\hline
\end{tabular}




\begin{tabular}{|c|c|c|c|c|c|}
\hline $\begin{array}{l}\text { Boatwright et } \\
\text { al. (2007) }\end{array}$ & $\begin{array}{l}\text { Critics' reviews (volume } \\
\text { and valence) }\end{array}$ & $\begin{array}{l}\text { Production budget, Communication } \\
\text { budget, Presence of stars, Screens, } \\
\text { Movie's appeal }\end{array}$ & $\begin{array}{l}\text { Revenues (opening } \\
\text { week), Decay rate } \\
\text { of sales }\end{array}$ & $\begin{array}{l}466 \text { movies }(1997 \\
-2001)\end{array}$ & $\begin{array}{l}\text { Sequels are a characteristic of the films. } 8 \% \text { of a sub-sample } \\
\text { ( } 317 \text { movies) are sequels. Sequels have the greater market } \\
\text { potential. }\end{array}$ \\
\hline $\begin{array}{l}\text { Basuroy } \\
\text { Chatterjee } \\
(2008)\end{array}$ & $\begin{array}{l}\text { Critics' reviews (volume } \\
\text { and valence) }\end{array}$ & $\begin{array}{l}\text { Screens, Movie characteristics (MPAA } \\
\text { ratings, Director or actor awards, } \\
\text { Production budget), Seasonality }\end{array}$ & $\begin{array}{l}\text { Domestic revenues } \\
\text { (for up to the } \\
\text { fifteenth week) }\end{array}$ & $\begin{array}{l}167 \quad \text { movies } \\
(1991-1993)\end{array}$ & $\begin{array}{l}\text { Sequels are considered as a brand extension. } 11 \text { films are } \\
\text { sequels in the database. The sequel's box office performance } \\
\text { is weaker than the original movie's performance but higher } \\
\text { than the contemporaneous non-sequels' performance. }\end{array}$ \\
\hline $\begin{array}{l}\text { Moon et al. } \\
(2010)\end{array}$ & $\begin{array}{l}\text { Critics' reviews (volume } \\
\text { and valence), Consumer } \\
\text { reviews (volume and } \\
\text { valence) }\end{array}$ & $\begin{array}{l}\text { Movie characteristics (genre, sequel, } \\
\text { MPAA ratings, distribution, films life, } \\
\text { video release lagging days), Movie } \\
\text { costs (production budget, advertising } \\
\text { expenditure, screens) }\end{array}$ & $\begin{array}{l}\text { Revenues (box } \\
\text { office, video rental, } \\
\text { video sales) }\end{array}$ & $\begin{array}{l}246 \text { movies }(2003 \\
-2005)\end{array}$ & $\begin{array}{l}\text { Sequels are considered as a brand extension. } 36 \text { films are } \\
\text { sequels in the database. Sequels have a positive impact on } \\
\text { revenues only in the first two weeks but receive lower } \\
\text { ratings than originals. }\end{array}$ \\
\hline $\begin{array}{l}\text { Karniouchina } \\
\text { (2011) }\end{array}$ & $\begin{array}{l}\text { Consumer reviews (volume } \\
\text { and valence, pre- and post- } \\
\text { release, movie and star) }\end{array}$ & $\begin{array}{l}\text { Movie characteristics (advertising } \\
\text { budget, sequel, nationality), Stars' } \\
\text { characteristics (bankability, recency of } \\
\text { success, academy awards, sex appeal) }\end{array}$ & $\begin{array}{l}\text { Revenues (opening } \\
\text { week, second week } \\
\text { and beyond) }\end{array}$ & $\begin{array}{l}140 \\
(2005)\end{array}$ & $\begin{array}{l}\text { Sequels are considered as a control variable. Number of } \\
\text { sequels in the database is not specified. The volume of } \\
\text { reviews is higher for sequels. }\end{array}$ \\
\hline $\begin{array}{l}\text { Dhar et al. } \\
(2012)\end{array}$ & $\begin{array}{l}\text { Consumer } \\
\text { (valence) }\end{array}$ & $\begin{array}{l}\text { Movie characteristics (MPAA ratings, } \\
\text { genre, run time), Seasonality (month, } \\
\text { holiday) }\end{array}$ & $\begin{array}{l}\text { Revenues (opening } \\
\text { week, total) }\end{array}$ & $\begin{array}{l}1,990 \quad \text { movies } \\
(1983-2008)\end{array}$ & $\begin{array}{l}\text { Sequels represent } 6,68 \% \text { of the database. Sequels have a } \\
\text { better box office performance than non-sequels but they } \\
\text { generate less attendance than original movies. }\end{array}$ \\
\hline $\begin{array}{l}\text { Hennig- } \\
\text { Thurau et al. } \\
\text { (2012) }\end{array}$ & $\begin{array}{l}\text { Critics' reviews (valence), } \\
\text { Consumer reviews } \\
\text { (valence) }\end{array}$ & $\begin{array}{l}\text { Movie characteristics (star power, } \\
\text { sequel, MPAA ratings, genre), Target } \\
\text { audiences, Studios' actions (advertising } \\
\text { expenditures, release strategy), Buzz } \\
\text { (prerelease) }\end{array}$ & $\begin{array}{l}\text { Revenues (first } \\
\text { week, after the first } \\
\text { week) }\end{array}$ & $\begin{array}{l}1,370 \quad \text { movies } \\
(1998-2006)\end{array}$ & $\begin{array}{l}\text { Sequels are a characteristic of the films. Number of sequels } \\
\text { in the database is not specified. The influence of reviews on } \\
\text { the box office performance is weaker for a sequel than for a } \\
\text { contemporaneous non-sequel. }\end{array}$ \\
\hline $\begin{array}{l}\text { Akdeniz \& } \\
\text { Talay (2013) }\end{array}$ & Critics' reviews (valence) & $\begin{array}{l}\text { Movie characteristics (production } \\
\text { budget, sequel, star power, genre, }\end{array}$ & $\begin{array}{l}\text { Revenues } \\
\text { week) }\end{array}$ & $\begin{array}{l}1,116 \quad \text { movies } \\
(2007-2011)\end{array}$ & $\begin{array}{l}103 \text { films are sequels. The positive relationship between } \\
\text { sequels and box office performance persists internationally. }\end{array}$ \\
\hline
\end{tabular}




\begin{tabular}{|c|c|c|c|c|c|c|}
\hline & & & $\begin{array}{l}\text { awards), Screens, Advertising } \\
\text { expenditures, Characteristic of the } \\
\text { distributor (major), Seasonality, } \\
\begin{array}{l}\text { Competing movies (including local } \\
\text { movies) }\end{array}\end{array}$ & & & $\begin{array}{l}\text { However, this relationship varies by culture (e.g., the } \\
\text { relationship wanes in individualist cultures versus } \\
\text { collectivist cultures). }\end{array}$ \\
\hline $\begin{array}{l}\text { Bharadwaj } \\
\text { al. (2017) }\end{array}$ & et & $\begin{array}{l}\text { Critics' reviews (volume, } \\
\text { valence, writing style) }\end{array}$ & $\begin{array}{l}\text { Sequel, Genre, Production budget, } \\
\text { Advertising budget, MPAA ratings, } \\
\text { Director power, Star power, Level of } \\
\text { competition, Studio, Release }\end{array}$ & $\begin{array}{l}\text { Domestic revenues } \\
\text { (total) }\end{array}$ & $\begin{array}{l}115 \quad \text { movies } \\
(2009-2011)\end{array}$ & $\begin{array}{l}\text { Number of sequels in the database is not specified. Sequels } \\
\text { - considered as a prelaunch marketing decision - have a } \\
\text { significant impact on box office performance. }\end{array}$ \\
\hline $\begin{array}{l}\text { Filson } \\
\text { Havlicek } \\
(2018)\end{array}$ & $\&$ & $\begin{array}{l}\text { Critics' reviews (valence), } \\
\text { Consumer reviews } \\
\text { (valence) }\end{array}$ & $\begin{array}{l}\text { Production budget, Advertising } \\
\text { expenditures, Genre, MPAA ratings, } \\
\text { Screens, Awards, Change in the } \\
\text { franchise (ratings, lead actor, director) }\end{array}$ & $\begin{array}{l}\text { Revenues (domestic } \\
\text { and foreign } \\
\text { markets) and ROI } \\
\text { (revenues / budget) }\end{array}$ & $\begin{array}{l}433 \text { movies (prior } \\
\text { to } 2014 \text { ) }\end{array}$ & $\begin{array}{l}\text { The box office performance of franchises deteriorates as } \\
\text { installments are introduced. Part of the box office revenues } \\
\text { attributable to foreign markets rises as further installments } \\
\text { are introduced. }\end{array}$ \\
\hline
\end{tabular}


Table 2 - Summary of the data sample

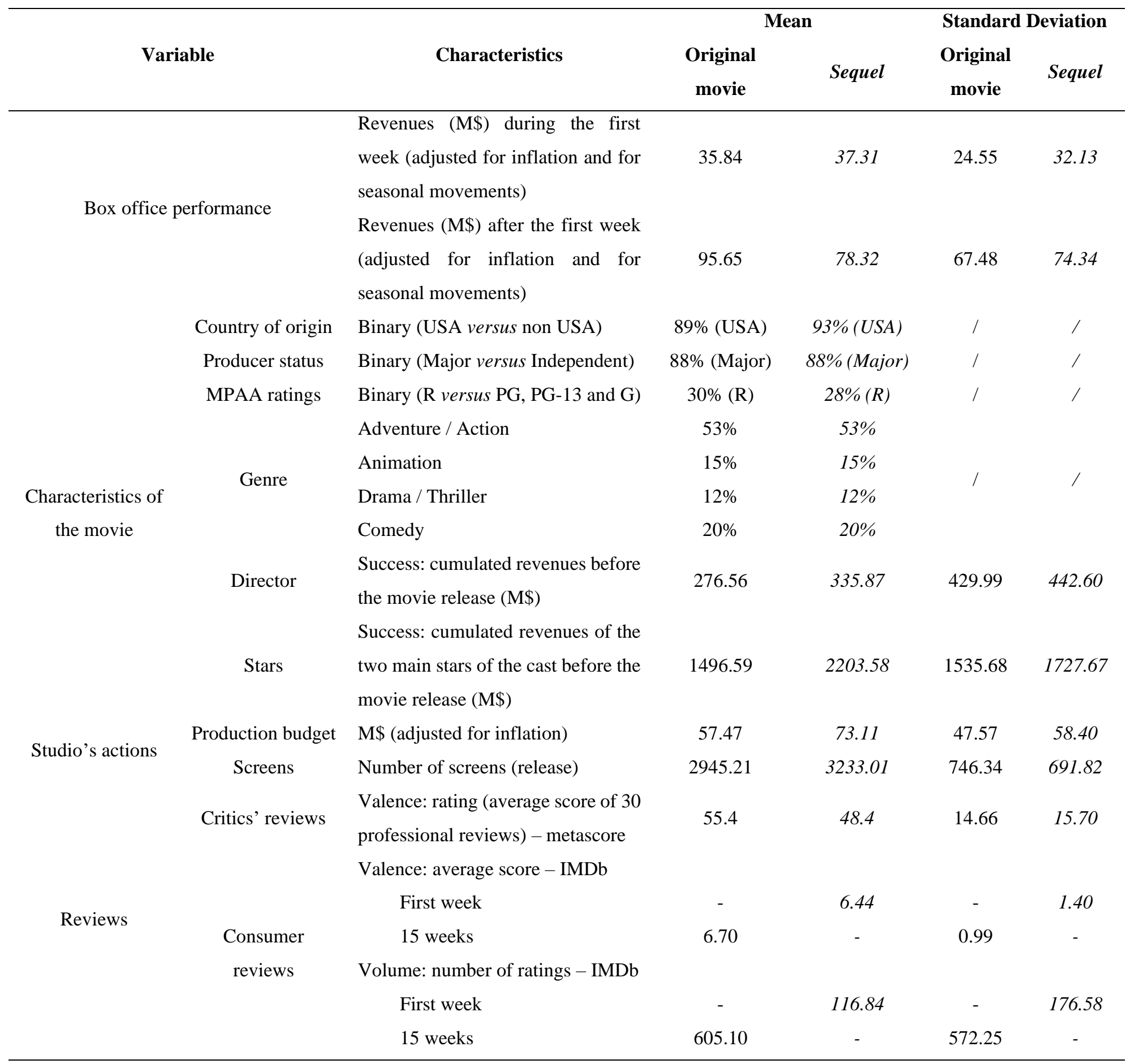


Table 3 - Model of the sequel's box office performance: intra-movie perspective

\begin{tabular}{|c|c|c|c|c|c|c|}
\hline \multirow{2}{*}{$\begin{array}{c}\text { Endogenous } \\
\text { variables }\end{array}$} & \multicolumn{3}{|c|}{ First week } & \multicolumn{3}{|c|}{ After the first week } \\
\hline & Budget & Screens & Revenue & Budget & Screens & Revenue \\
\hline \multicolumn{7}{|l|}{ Exogenous variables } \\
\hline Production budget & - & $0.203 * * *$ & $0.251 * * *$ & - & $0.211 * * *$ & $0.254 * * *$ \\
\hline Number of screens & - & - & $1.695 * * *$ & - & - & $1.365^{* * *}$ \\
\hline Country of origin & 0.021 & -0.079 & 0.211 & 0.026 & -0.075 & 0.105 \\
\hline Producer status & 0.089 & -0.026 & -0.053 & 0.093 & -0.026 & 0.018 \\
\hline Genre (Adventure / Action) & $0.273 * * *$ & 0.007 & 0.052 & $0.274 * * *$ & 0.006 & -0.015 \\
\hline Genre (Animation) & $0.331 * * *$ & $0.225 * * *$ & 0.047 & $0.323 * * *$ & $0.221 * * *$ & 0.220 \\
\hline Genre (Drama / Thriller) & 0.121 & 0.054 & 0.064 & 0.096 & 0.089 & 0.025 \\
\hline MPAA ratings $(\mathrm{R})$ & $0.186^{* * *}$ & 0.070 & -0.028 & $0.192 * * *$ & 0.075 & $0.248 * * *$ \\
\hline Success of the director & $0.169 * * *$ & $0.118^{*}$ & 0.030 & $0.181 * *$ & $0.117^{*}$ & 0.033 \\
\hline Success of the stars & -0.122 & -0.034 & -0.009 & -0.123 & -0.026 & -0.012 \\
\hline Critics' reviews (valence) & - & - & $0.584 * * *$ & - & - & 0.474 \\
\hline Consumer reviews (valence) & - & - & - & - & - & $0.441 * * *$ \\
\hline Consumer reviews (volume) & - & - & - & - & - & $0.420 * *$ \\
\hline Adjusted $\mathrm{R}^{2}$ & 0.662 & 0.654 & 0.633 & 0.662 & 0.654 & 0.772 \\
\hline
\end{tabular}

*** significant at the $1 \%$ level, $* *$ at the $5 \%$ level, * at the $10 \%$ level 
Table 4 - Direct and indirect effects of the original movie's reviews on the sequel's box office performance through the sequel's reviews ${ }^{7}$

\begin{tabular}{|c|c|c|c|c|c|c|}
\hline \multirow[b]{2}{*}{$\begin{array}{c}\text { Reviews original } \\
\text { movie }\end{array}$} & \multirow[b]{2}{*}{$\begin{array}{c}\text { Box office } \\
\text { performance sequel }\end{array}$} & \multirow{2}{*}{$\begin{array}{c}\text { Direct effect } \\
\text { Reviews original movie } \\
\rightarrow \text { Box office } \\
\text { performance } \text { sequel } \\
\text { (c) }\end{array}$} & \multicolumn{3}{|c|}{ Indirect effect } & \multirow[b]{2}{*}{$\begin{array}{c}\text { Total } \\
\text { effect } \\
\text { a } \times \text { b + } \mathbf{c}^{8}\end{array}$} \\
\hline & & & $\begin{array}{c}\text { Reviews original movie } \\
\rightarrow \text { Reviews sequel } \\
\text { (a) }\end{array}$ & $\begin{array}{c}\text { Reviews sequel } \rightarrow \\
\text { Box office } \\
\text { performance sequel } \\
\text { (b) }\end{array}$ & $\begin{array}{l}\text { Indirect effect } \\
\qquad(\mathbf{a} \times \mathbf{b})\end{array}$ & \\
\hline Consumer & First week & $0.458^{*}$ & - & - & - & - \\
\hline $\begin{array}{l}\text { reviews } \\
\text { (valence) }\end{array}$ & $\begin{array}{l}\text { After the first } \\
\text { week }\end{array}$ & 0.066 & $0.484 * * *$ & $0.180 *$ & $0.087 *$ & $0.153 *$ \\
\hline Consumer & First week & $0.129 * * *$ & - & - & - & - \\
\hline $\begin{array}{l}\text { reviews } \\
\text { (volume) }\end{array}$ & $\begin{array}{l}\text { After the first } \\
\text { week }\end{array}$ & -0.183 & $0.837 * * *$ & $0.409 * * *$ & $0.343 * *$ & $0.159 *$ \\
\hline Critics' & First week & -0.018 & $0.701 * *$ & 0.011 & 0.008 & -0.010 \\
\hline reviews & $\begin{array}{l}\text { After the first } \\
\text { week }\end{array}$ & 0.092 & $0.701 * *$ & -0.043 & -0.030 & 0.062 \\
\hline
\end{tabular}

\footnotetext{
${ }^{7}$ The model is just-identified. Fit indices are not significant $(\mathrm{RMSEA}=0 ; \mathrm{CFI}=1 ; \mathrm{TLI}=1)$.

${ }^{8}$ The total variance of $\mathrm{Y}$ explained by $\mathrm{X}$ is based on a direct effect $c(\mathrm{X} \rightarrow \mathrm{Y})$ and an indirect effect $a \times b(a \mathrm{X} \rightarrow$ mediator and $b$ mediator $\rightarrow \mathrm{Y}$ ).
} 
Table 5 - Moderating effect of the time interval on the relation between original movie's reviews and sequel's performance ${ }^{9}$

\begin{tabular}{ccc}
\hline & & First week \\
\hline \multirow{2}{*}{ Consumer reviews } & Valence & -0.009 \\
Critics' reviews & Volume & $-0.005 *$ \\
*** significant at the 1\% level, ** at the 5\% level, * at the $10 \%$ level
\end{tabular}

Table 6 - Results summary

${ }^{9}$ Only the interaction coefficient is reported. 


\begin{tabular}{|c|c|c|c|}
\hline \multicolumn{2}{|c|}{ Hypothesis } & \multirow{2}{*}{$\begin{array}{l}\text { Expected result } \\
\text { Effect: }+\end{array}$} & \multirow{2}{*}{$\begin{array}{l}\text { Empirical result } \\
\text { Supported }\end{array}$} \\
\hline & Reviews (vol. consumers) original movie $\rightarrow$ Short-term box office sequel & & \\
\hline & Reviews (vol. consumers) original movie $\rightarrow$ Long-term box office ${ }_{\text {sequel }}$ & No effect & Supported \\
\hline \multicolumn{4}{|l|}{ H1a } \\
\hline & Reviews (val. consumers) original movie $\rightarrow$ Short-term box office sequel & Effect: + & Supported \\
\hline & Reviews (val. consumers) original movie $\rightarrow$ Long-term box office ${ }_{\text {sequel }}$ & No effect & Supported \\
\hline & Reviews (val. critics) original movie $\rightarrow$ Short-term box office sequel & Effect: + & Not supported \\
\hline & Reviews (val. critics) original movie $\rightarrow$ Long-term box office sequel & No effect & Supported \\
\hline \multirow{3}{*}{$\mathbf{H 2}$} & Time interval $\rightarrow$ [Reviews (vol. consumers) original movie $\rightarrow$ Short-term box office sequel] & Moderation effect: + & Supported \\
\hline & Time interval $\rightarrow$ [Reviews (val. consumers) original movie $\rightarrow$ Short-term box office ${ }_{\text {sequel }}$ ] & Moderation effect: + & Not supported \\
\hline & Time interval $\rightarrow$ [Reviews (val. critics) original movie $\rightarrow$ Short-term box office sequel $]$ & Moderation effect: + & Not supported \\
\hline \multirow{2}{*}{ H3a } & $\begin{array}{l}\text { Reviews (vol. consumers) original movie } \rightarrow \text { Reviews (vol. consumers) } \text { sequel }^{\rightarrow} \text { Long-term } \\
\text { box office }{ }_{\text {sequel }}\end{array}$ & Effect: + & Supported \\
\hline & $\begin{array}{l}\text { Reviews (val. consumers) original movie } \rightarrow \text { Reviews (val. consumers) } \text { sequel }^{\rightarrow} \text { Long-term } \\
\text { box office sequel }\end{array}$ & Effect: + & Supported \\
\hline H3b & $\begin{array}{l}\text { Reviews (val. critics) original movie } \rightarrow \text { Reviews (val. critics) } \text { sequel }^{\rightarrow} \text { Long-term box } \\
\text { office }_{\text {sequel }}\end{array}$ & Effect: + & Not supported \\
\hline
\end{tabular}

Figure 1 - Conceptual model 


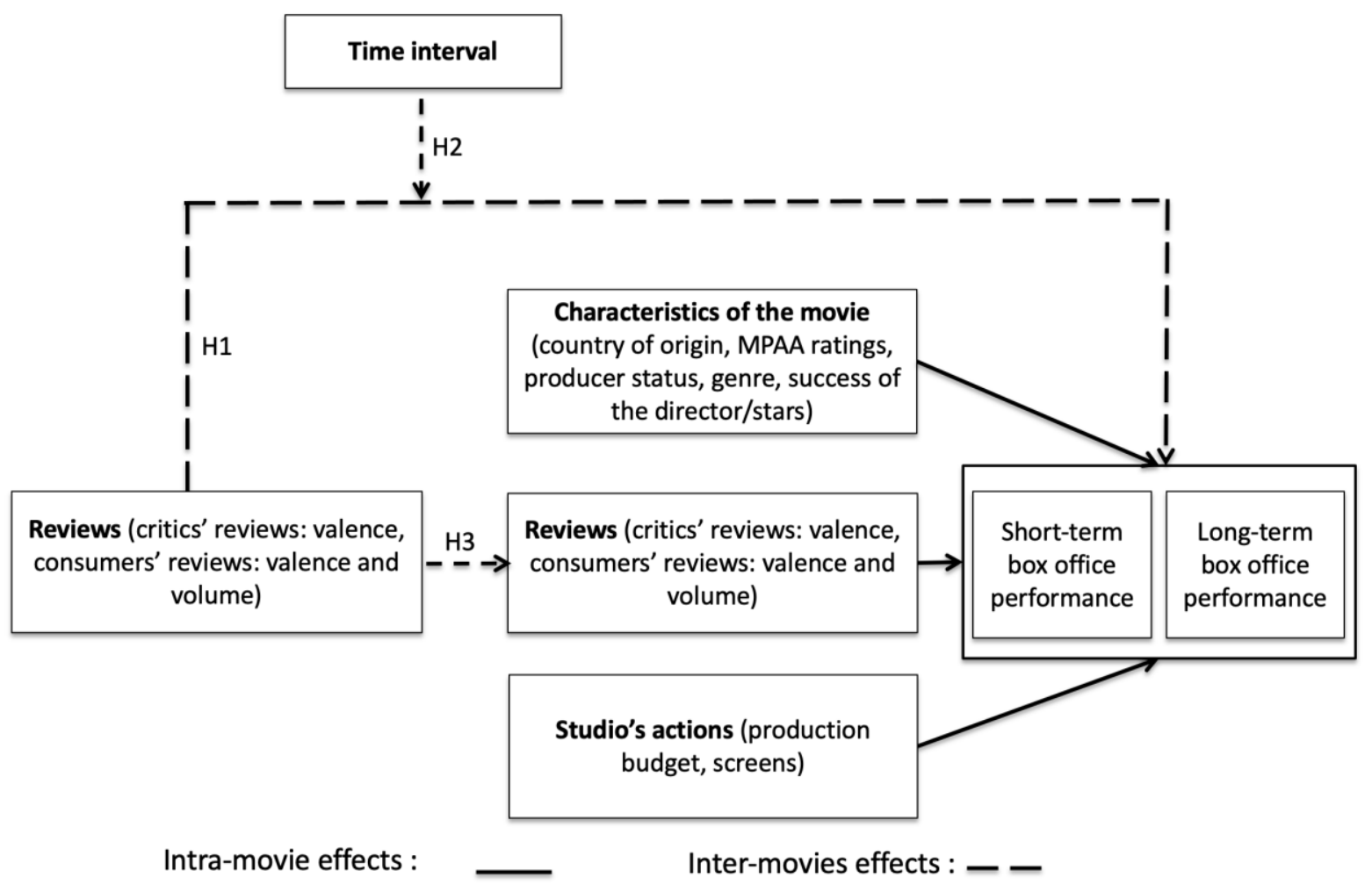

\section{References}


Aaker, D. A., \& Keller, K. L. (1990). Consumer evaluations of brand extensions. Journal of Marketing, 54(1), 27-41. https://doi.org/10.1177\%2F002224299005400102

Akdeniz, M. B., \& Talay, M. B. (2013). Cultural variations in the use of marketing signals: A multilevel analysis of the motion picture industry. Journal of the Academy of Marketing Science, 41(5), 601-624. https://doi.org/10.1007/s11747-013-0338-5

Akerlof, G. A. (1970). The market for 'lemons': quality uncertainty and the market mechanism. Quarterly Journal of Economics, 84(3), 488-500. https://doi.org/10.2307/1879431

Basuroy, S., \& Chatterjee, S. (2008). Fast and frequent: investigating box office revenues of motion picture sequels. Journal of Business Research, 61(7), 798-803. https://doi.org/10.1016/j.jbusres.2007.07.030

Basuroy, S., Chatterjee, S., \& Ravid, S. A. (2003). How critical are critical reviews? The box office effects of film critics, star power, and budgets. Journal of Marketing, 67(4), 103117. https://doi.org/10.1509\%2Fjmkg.67.4.103.18692

Basuroy, S., Desai, K. K., \& Takuldar, D. (2006). An empirical investigation of signaling in the motion picture industry. Journal of Marketing Research, 43(2), 287-295. https://doi.org/10.1509\%2Fjmkr.43.2.287

Bharadwaj, N., Noble, C. H., Tower, A., Smith, L. M., \& Dong, Y. (2017). Predicting innovation success in the motion picture industry: The influence of multiple quality signals. Journal of Product Innovation Management, 34(5), 659-680. https://doi.org/10.1111/jpim.12404

Berger, J., \& Schwartz, E. M. (2011). What drives immediate and ongoing word of mouth?. Journal of Marketing Research, 48(5), 869-880. https://doi.org/10.1509\%2Fjmkr.48.5.869 
Boatwright, P., Basuroy, S., \& Kamakura, W. (2007). Reviewing the reviewers: The impact of individual film critics on box office performance. Quantitative Marketing and Economics, 5(4), 401-425. https://doi.org/10.1007/s11129-007-9029-1

Carrillat, F. A., Legoux, R., \& Hadida, A. L. (2018). Debates and assumptions about motion picture performance: A meta-analysis. Journal of the Academy of Marketing Science, 46(2), 273-299. https://doi.org/10.1007/s11747-017-0561-6

Chakravarty, A., Liu, Y., \& Mazumdar, T. (2010). The differential effects of online word-ofmouth and critics' reviews on pre-release movie evaluation. Journal of Interactive Marketing, 24(3), 185-197. https://doi.org/10.1016/j.intmar.2010.04.001

Chen, Y., Liu, Y., \& Zhang, J. (2012). When do third-party product reviews affect firm value and what can firms do? The case of media critics and professional movie reviews. Journal of Marketing, 76(2), 116-134. https://doi.org/10.1509\%2Fjm.09.0034

Chisholm, D. C., Fernández-Blanco, V., Ravid, S. A., \& Walls, W. D. (2015). Economics of motion pictures: the state of the art. Journal of Cultural Economics, 39(1), 1-13. https://doi.org/10.1007/s10824-014-9234-1

Dellarocas, C., Gao, G., \& Narayan, R. (2010). Are consumers more likely to contribute online reviews for hit or niche products? Journal of Management Information Systems, 27(2), 127-158. https://doi.org/10.2753/MIS0742-1222270204

Dellarocas, C., Zhang, X. M., \& Awad, N. F. (2007). Exploring the value of online product reviews in forecasting sales: The case of motion pictures. Journal of Interactive Marketing, 21(4), 23-45. https://doi.org/10.1002/dir.20087

Desai, K. K., \& Basuroy, S. (2005). Interactive influence of genre familiarity, star power, and critics' reviews in the cultural goods industry: The case of motion pictures. Psychology \& Marketing, 22(3), 203-223. https://doi.org/10.1002/mar.20055 
Dhar, T., Sun, G., \& Weinberg, C. B. (2012). The long-term box office performance of sequel movies. Marketing Letters, 23(1), 13-29. https://doi.org/10.1007/s11002-011-9146-1

Duan, W., Gu, B., \& Whinston, A. B. (2008). The dynamics of online word-of-mouth and product sales - an empirical investigation of the movie industry. Journal of Retailing, 84(2), 233-242. https://doi.org/10.1016/j.jretai.2008.04.005

Elberse, A., \& Eliashberg, J. (2003). Demand and supply dynamics for sequentially released products in international markets: The case of motion pictures. Marketing Science, 22(3), 329-354. https://doi.org/10.1287/mksc.22.3.329.17740

Eliashberg, J., Elberse, A., \& Leenders, M. A. (2006). The motion picture industry: Critical issues in practice, current research, and new research directions. Marketing Science, 25(6), 638-661. https://doi.org/10.1287/mksc.1050.0177

Feldman, J. M., \& Lynch, J. G. (1988). Self-generated validity and other effects of measurement on belief, attitude, intention, and behavior. Journal of Applied Psychology, 73(3), 421-435. https://psycnet.apa.org/doi/10.1037/0021-9010.73.3.421

Filson, D., \& Havlicek, J. (2018). The performance of global film franchises: installment effects and extension decisions. Journal of Cultural Economics, 42(3), 447-467. https://doi.org/10.1007/s10824-018-9316-6

Godes, D. \& Mayzlin, D. (2004). Using online conversations to study word-of-mouth communication. Marketing Science, 23(4), 545-560. https://doi.org/10.1287/mksc.1040.0071

Godes, D., \& Silva, J. C. (2012). Sequential and temporal dynamics of online opinion. Marketing Science, 31(3), 448-473. https://doi.org/10.1287/mksc.1110.0653

Hadida, A. L. (2009). Motion picture performance: A review and research agenda. International Journal of Management Reviews, 11(3), 297-335. https://doi.org/10.1111/j.1468-2370.2008.00240.x 
Hennig-Thurau, T., Houston, M. B., \& Heitjans, T. (2009). Conceptualizing and measuring the monetary value of brand extensions: the case of motion pictures. Journal of Marketing, 73(6), 167-183. https://doi.org/10.1509\%2Fjmkg.73.6.167

Hennig-Thurau, T., Houston, M. B., \& Sridhar, S. (2006). Can good marketing carry a bad product? Evidence from the motion picture industry. Marketing Letters, 17(3), 205-219. https://doi.org/10.1007/s11002-006-7416-0

Hennig-Thurau, T., Marchand, A., \& Hiller, B. (2012). The relationship between reviewer judgments and motion picture success: re-analysis and extension. Journal of Cultural Economics, 36(3), 249-283. https://doi.org/10.1007/s10824-012-9172-8

Hennig-Thurau, T., Wiertz, C., \& Feldhaus, F. (2015). Does Twitter matter? The impact of microblogging word of mouth on consumers' adoption of new movies. Journal of the Academy of Marketing Science, 43(3), 375-394. https://doi.org/10.1007/s11747-014-0388$\underline{3}$

Holbrook, M. B. (2005). The role of ordinary evaluations in the market for popular culture: Do consumers have "good taste"? Marketing Letters, 16(2), 75-86. https://doi.org/10.1007/s11002-005-2774-6

Joshi, A., \& Mao, H. (2012). Adapting to succeed? Leveraging the brand equity of best sellers to succeed at the box office. Journal of the Academy of Marketing Science, 40(4), 558-571. https://doi.org/10.1007/s11747-010-0241-2

Karniouchina, E. V. (2011). Impact of star and movie buzz on motion picture distribution and box office revenue. International Journal of Research in Marketing, 28(1), 62-74. https://doi.org/10.1016/j.ijresmar.2010.10.001

Knapp, A. K., Hennig-Thurau, T., \& Mathys, J. (2014). The importance of reciprocal spillover effects for the valuation of bestseller brands: introducing and testing a 
contingency model. Journal of the Academy of Marketing Science, 42(2), 205-221. https://doi.org/10.1007/s11747-013-0350-9

King, R. A., Racherla, P., \& Bush, V. D. (2014). What we know and don't know about online word-of-mouth: a review and synthesis of the literature. Journal of Interactive Marketing, 28(3), 167-183. https://doi.org/10.1016/j.intmar.2014.02.001

Larceneux, F. (2007). Buzz and recommendations on the Internet. What impacts on boxoffice success? Recherche et Applications en Marketing, 22(3), 45-64. https://doi.org/10.1177\%2F205157070702200304

Lazear, E. P. (2004). The Peter Principle: A theory of decline. Journal of Political Economy, 112(S1), 141-163. https://doi.org/10.1086/379943

Lee, Y. J., Hosanagar, K., \& Tan, Y. (2015). Do I Follow My Friends or the Crowd? Information Cascades in Online Movie Ratings. Management Science, 61(9), 2241-2258. https://doi.org/10.1287/mnsc.2014.2082

Liu, Y. (2006). Word of mouth for movies: its dynamics and impact on box office revenue. Journal of Marketing, 70(3), 74-89. https://doi.org/10.1509\%2Fjmkg.70.3.074

Moon, S., Bergey, P. K., \& Iacobucci, D. (2010). Dynamic effects among movie ratings, movie revenues, and viewer satisfaction. Journal of Marketing, 74(1), 108-121. https://doi.org/10.1509\%2Fjmkg.74.1.108

Nelson, P. (1970). Information and consumer behavior. Journal of Political Economy, 78(2), 311-329. https://doi.org/10.1086/259630

Prieto-Rodriguez, J., Gutierrez-Navratil, F., \& Ateca-Amestoy, V. (2015). Theatre allocation as a distributor's strategic variable over movie runs. Journal of Cultural Economics, 39(1), 65-83. https://doi.org/10.1007/s10824-014-9220-7 
Ravid, S. A. (1999). Information, blockbusters, and stars: A study of the film industry. The Journal of Business, 72(4), 463-492. https://doi.org/10.1086/209624

Rein, I. J., Kotler, P., \& Stoller, M. R. (1987). High visibility. UK, Heinemann Professional Publishing Ltd.

Sood, S., \& Drèze, X. (2006). Brand extensions of experiential goods: Movie sequel evaluations. Journal of Consumer Research, 33(3), 352-360.

https://doi.org/10.1086/508520

Zhao, X., Lynch Jr, J. G., \& Chen, Q. (2010). Reconsidering Baron and Kenny: Myths and truths about mediation analysis. Journal of Consumer Research, 37(2), 197-206. https://doi.org/10.1086/651257

Zufryden, F. S. (1996). Linking advertising to box office performance of new film releases-a marketing planning model. Journal of Advertising Research, 36(4), 29-42. 